ㄷ T. Hoffmann, professor, Uniwersytet Łódzki, Lódz, Polska

\title{
MOWA NIENAWIŚCI \\ NA PRZYKŁADZIE MEDIÓW SPOŁECZNOŚCIOWYCH - WYBRANE ASPEKTY MEDIOZNAWCZE I PRAWNE
}

\section{У статті розглядається дискурс мови ненависті на сто- рінках деяких медіа. Аналізується небезпека, що вони несуть, пропонуються засоби протидії. Протидія розгля- дається у медіазнавчому та юридичному аспектах. Не залишаються осторонь й електронні засоби масової інформації.}

\section{Ключові слова: мова; ненависть; медіа; юридичні аспекти; аспекти; електронні ЗМІ.}

\section{Wprowadzenie}

Cywilizacja cyfrowa rozwija się z coraz większym impetem a nowoczesne technologie zawłaszczają wszystkie sfery w których funkcjonuje człowiek. Jakość życia poszczególnych osób zanurzonych w sieci, nie zależy od ich wieku, lecz od poziomu posiadanych kompetencji informatycznych. Mimo wielu zalet świata wirtualnego i możliwości jakie on stwarza, generuje także pewnego rodzaju zagrożenia czy czasami nawet śmiertelną pułapkę dla niektórych jego użytkowników ${ }^{1}$.

Obecnie bardzo dużym zainteresowaniem cieszą się media społecznościowe. Szczególnie ludzie młodzi aktywnie korzystają z ich dobrodziejstwa, jednak nie brakuje także osób dojrzałych, które na co dzień uczestniczą w licznych dyskusjach prowadzonych na forum Facebooka.
0 ile korzystanie z portalu społecznościowego posiada niewątpliwie wiele zalet, nie można nie wspomnieć o pewnych wadach, szczególnie tych które wynikają z niewłaściwego ich wykorzystania.

Jednym $z$ aspektów często poruszanych zarówno na łamach literatury jak i w pragmatyce życia, są sytuacje w których osoby korzystające z Facebooka, używają w stosunku do innych użytkowników tzw. hate speech $\mathrm{tj}$. mowy nienawiści a zatem używania języka celem rozbudzenia nienawiści czy innych form kontestacji osoby, grupy osób czy jakiegokolwiek innego podmiotu2 2 .

Mowa nienawiści, może przybierać różne formy i w polskim systemie prawnym jest ona przestępstwem. Administratorzy Facebooka próbują zwalczać zachowania cechujące się mową nienawiści, jednak nie jest

${ }_{1}$ D. Morańska (red). Patologie w cyberprzestrzeni. Profilaktyka zagrożeń medialnych. Dąbrowa Górnicza. 2015. s. 309.

${ }^{2}$ Por. L. M. Nijakowski. Mowa nienawiści w świetle teorii dyskursu. W: A. Horolets. Analiza dyskursu w socjologii i dla socjologii. Toruń. 2008. s. 113-114.

(C) $2019 \mathrm{p}$. 
to takie łatwe. Z ostatnich badań wynika, że z 2,5 mln treści zawierających mowę nienawiści tylko $38 \%$ udało się wychwycić, co z kolei wskazuje iż obecnie algorytmy Facebooka nie są w stanie rozwiązać tego problemu3 3 . 0 tym jak istotny to jest problem próbuję wskazać w niniejszym artykule, którego celem jest charakterystyka mowy nienawiści w mediach społecznościowych na przykładzie Facebooka. Analizie zostało poddane pojęcie 'hate speech' a tym samym jej wpływ na psychikę człowieka. Posłużono się deskrypcją zachowań mających miejsce niekiedy na Facebooku jako najbardziej znanym i popularnym medium społecznościowym.

\section{Media Społecznościowe i ich istota}

Internet to forum wymiany poglądów i opinii, daje również pewnego rodzaju wrażenie anonimowości, które sprzyja powstawaniu wypowiedzi noszących cechy mowy nienawiści ${ }^{4}$. Od pewnego czasu w przestrzeni wirtualnej powstało i działa wiele tzw. social mediów o różnej proweniencji. Samo pojęcie mediów społecznościowych wywodzi się od angielskiego terminu, który to ma związek z technologiami internetowymi, technologią mobilną itp 5 . Początkowo były one wykorzystywane na urządzeniach stacjonarnych a obecnie za pomoca smartfonów i tabletów. Powstanie mediów społecznościowych jest związane z rozwojem Internetu i możliwościami jaki on daje w tym komunikacją. Już na początku lat $80 \mathrm{XX}$ wieku w Internecie powstawać zaczęły pierwsze grupy dyskusyjne, za pomocą których osoby mogły wymieniać się różnymi informacjami. W 1995 roku w Stanach Zjednoczonych powstał serwis Classmates.com, którego celem początkowo była możliwość odnajdywania przyjaciół z lat szkolnych. Koncepcja ta bardzo przypadła do gustu ich użytkownikom, że rozwiązania te zaczęto kopiować w innych państwach. Dekadę później w Polsce powstała jego kopia która początkowo nosiła nazwę Nasza Klasa przekształcona później w NK. W 2003 roku powstały Linkedln oraz WordPress. Rok później światło dzienne ujrzał popularny serwis społecznościowy jakim jest do dziś Facebook 6 . W Polsce jego na stałe zaczął być eksplorowany w 2008 roku.

Międzyczasie powstały inne serwisy społecznościowe takie jak: YouTube, Twitter, Instagram, Snapchat czy Google $+{ }^{7}$. Media te stały się jednym z kanałów komunikowania, w tym prowadzenia licznych rodzajów działalności. Osoby korzystające z mediów społecznościowych,

\footnotetext{
${ }^{3}$ Facebook przyznaje, że algorytmy nie radzą sobie z mową nienawiści i pokazuje ciekawe statystyki. https://www.spidersweb.pl/2018/05/facebook-mowa-nienawisci.html, data wejścia 11.07.2018.

${ }^{4} \mathrm{~J}$. Worona. Współczesne zagrożenia w cyberprzestrzeni. Aspekt prawno międzynarodowy, w: D. Morańska (red), Patologie w cyberprzestrzeni. Profilaktyka zagrożeń medialnych. Dąbrowa Górnicza. 2015. s. 79-85.

${ }^{5}$ Media społecznościowe, w: Encyklopedia Powszechna PWN, https://encyklopedia. pwn.pl/szukaj/media\%20spo\%C5\%82eczno\%C5\%9Bciowe.html, data wejścia 11.07.2018.

${ }^{6} \mathrm{~K}$. Garwol. Rola mediów społecznościowych w edukacji — stan obecny i perspektywy rozwoju. Dydaktyka Informatyki. 2017. \# 12. s. 52.

${ }^{7}$ Ibidem.
} 
zaczęli na nich upowszechniać filmy, muzykę, zdjęcia czy z czasem o wiele więcej treści. Głównym jednak założeniem mediów społecznościowych jest tworzenie i umacnianie relacji społecznych, nawiązywanie nowych znajomości i kontaktów, a także pielęgnowanie ich ${ }^{8}$. Jednym z najpopularniejszych narzędzi w ramach mediów społecznościowych jest Facebook. Został on założony przez studentów Harvardu początkowo miał zaspokajać potrzeby uczniów $^{9}$. Z czasem jednak przeistoczył się w bardzo popularny portal, zrzeszających ludzi, którzy czują potrzebę uspołeczniania się, komunikowania i podtrzymywanie wzajemnych więzi. Również zmieniały się jego funkcjonalności, takie jak udostępnianie treści, zdjęć, możliwość komentowania czy prowadzenia transmisji video na żywo ${ }^{10}$. Istotną rolę spajającą więzi pomiędzy użytkownikami Facebooka są możliwości tworzenia różnych grup o podobnych bądź tożsamych zainteresowaniach. Za jego pomocą można także prowadzić działalność komercyjną wspomaganą i promowaną w odpowiedni sposób co bezpośrednio przekłada się na popularność tego medium ${ }^{11}$.

Portal ten zaczęli również efektywnie wykorzystywać politycy. Co niektórzy prowadzili nawet kampanie wyborcze $z$ wykorzystaniem technik interaktywnych na portalach społecznościowych, gdyż istnieje na nich wiele metod i form komunikacji, do których zalicza się przede wszystkim: fora, blogi, fora dyskusyjne ${ }^{12}$.

Facebook stał się ogromnym fenomenem a jego sukces spowodował, że z portalu tego korzystaja nie tylko zwyczajni ludzie ale także znane osoby, celebryci czy autorytety. Osoby te tworzą swoje profile a tym samym są na bieżąco z licznymi wydarzeniami czy życiem społecznym. Mogą oni komunikować się z innymi a tym samym brać udział w akacjach społecznych, działaniach czy promowaniu własnych projektów a nawet ostatnio prowadzić kampanię wyborczą co zostało dodatkowo wsparte przez administrację Facebooka, która w 2012 roku w związku ze zbliżającą się kampanią wyborczą w USA wystąpiła z inicjatywą kooperacji w wyborach politycznych.

Stworzono specjalne zakładki i przyciski, które pomagały stworzyć profile wyborcze, a tym samym prowadzić kampanię prezentując swoje ideały, system wartości oraz przede wszystkim swój program polityczny13. Trend ten został również reali-

\footnotetext{
8M. Grębosz; D. Siuda; G. Szymański. Social media marketing. Monografie Politechniki Łódzkiej. Łódź. 2016. s. 22; P. Szczypa; A. Lulek. Media społecznościowe jako źródło informacji sprawozdawczych w przyszłości. Zeszyty Uniwersytetu Ekonomicznego w Katowicach. Katowice. 2017. s. 9.

${ }^{9}$ D. Kirpatrick. Efekt Facebooka. Warszawa. 2011. s. 206-207.

${ }^{10}$ A. Bąk. Serwisy społecznościowe - efekt Facebooka i nie tylko. Media i Społeczeństwo: medioznawstwo, komunikologia, semiologia, socjologia mediów. Tom 6 . BielskoBiała. 2016. s. 142.

11 /bidem. s. 143.

${ }^{12} \mathrm{P}$. Frankowski A. Juneja, Serwisy społecznościowe. Budowa, administracja i moderacja. Gliwice. 2009. s. 23.

${ }^{13}$ Getting Started, w: Facebook Politics \& Government, https://politics.fb.com, data wejścia 11.07.2018.
} 
zowany w Polsce, co przejawiało się w tworzeniu profili nie tylko przez osoby ale także instytucje publiczne, takie jak Biuro Bezpieczeństwa Narodowego, Kancelarię Prezydenta RP, Ministerstwo Finansów, Sąd Najwyższy czy Narodowy Bank Polski, Ministerstwo Gospodarki oraz Ministerstwo Infrastruktury i Rozwoju. W przypadku osób publicznych dominują głównie konta aktywnych polityków z polskiej sceny politycznej14. Wraz z rozwojem technologii cyfrowych, człowiek posiadł znaczące możliwości rozwoju, publikowania, komentowania czy wykonywania czynności, które do tej pory były dla niego niedostępne. Tym samym unowocześnieniu uległa komunikacja pomiędzy użytkownikami social mediów, która dobrze spożytkowana i ukierunkowana może przynieść wiele niebywałych korzyści oraz potencjalny rozgłos. Mimo tych niewątpliwie pozytywnych aspektów należy zaznaczyć iż tylko rozsądnie stosowana technologia cyfrowa może ułatwiać życie, jednak jej nadmiar prowadzi do destrukcji.

Podkreślić należy że nowatorskość i zarazem efektywność Facebooka wiąże się z tym że pozwala on przeciętnemu jego użytkownikowi na pozostawianie znacznej ilości infor- macji o tym co lubi, na jakie tematy dyskutuje, jakich znajomych posiada, jakie posiada zainteresowania, w jakich dziedzinach używa mediów społecznościowych, jakie ma preferencje seksualne, wyznanie, płeć, kolor skóry, czy poglądy polityczne ${ }^{15}$. Te wszystkie determinanty powodują że aktywność na portalu społecznościowym przestaje być anonimizowana, a tym samym może prowadzić do szerszego dyskursu pomiędzy użytkownikami. Ów dyskurs jednak dość często przeradza się w zwykły hejt lub co gorsza mowę nienawiści, która z samej istoty jest destrukcyjna.

\section{Mowa nienawiści na Facebooku}

Internet stał się nowoczesną bazą techniczną dla struktury organizacyjnej współczesnej epoki informacji. Jego możliwości są nieograniczone, co doprowadziło do powstania tzw. wysoce zróżnicowanej siatki sfer publicznych. Ten nieskrępowany rezerwuar treści, stał się dobrem wspólnym wszystkich korzystających z niego ${ }^{16} \mathrm{w}$ tym bardzo popularne stało się korzystanie z serwisów społecznościowych, które odpowiednio dawkowane jest pożądane. Ograniczyć je należy w przypadku osób, które w życiu wirtualnym wykazują

\footnotetext{
14Takie jak Janusz Palikot (189898 obserwatorów), Ryszard Kalisz (47235 obserwatorów) oraz Adam Hofman (43695 obserwatorów). W rankingu na najbardziej obserwowaną 'twarz rządu' wygrał Radosław Sikorski (166223 obserwatorów), Donald Tusk (99414 obserwatorów) oraz Paweł Graś (50890 obserwatorów). Natomiast w kwestii najbardziej obserwowanych urzędów, na podium uplasowała się Kancelaria Premiera (63599 obserwatorów), Ministerstwo Spraw Zagranicznych RP (11682 obserwatorów) oraz Ministerstwo Obrony (4345 obserwatorów).

${ }^{15}$ A. Gruszczyk. Moja prawda jest najmojsza czyli postprawda w praktyce [w:] T. Grabowski, M. Łakomy, K. Oświęcimski (red). Postprawda jako zagrożenie dyskursu publicznego. Kraków 2018. s. 58.

${ }^{16} \mathrm{~A}$. Demczuk. Postprawda i mowa nienawiści jako nowe narzędzia prowadzenia polityki w społeczeństwie informacyjnym, [w:] T. Grabowski, M. Łakomy, K. Oświęcimski (red). Postprawda jako zagrożenie dyskursu publicznego. Kraków. 2018. s. 174.
} 
problemy społeczne, korzystając np. Z Facebooka ludzie nie uczą się zachowań społecznych, mogą natomiast ujawniać swoje prawdziwe zachowania, więc często zdarza się, że robią coś, co jest nieprzemyślane bądź niemądre. Negatywnym efektem działalności na portalach społecznościowych w tym na Facebooku są zachowania osób które w komunikacji posługują się mową nienawiści czy zwykłym hejtem.

Jeśli chodzi o hejt stał on się bardzo popularny jako forma rozładowania swoich emocji. W obecnych czasach kiedy normalne ludzkie spotkania i więzi zostały zastąpione przez spotkania w świecie wirtualnym komunikacja ludzka bardzo często kończy się konfliktami. To jakby odpowiedź systemu nerwowego człowieka, który kiedyś mógł rozładować swoje napięcie w licznych organizacjach społecznych a obecnie wykonuje to w mediach społecznościowych w których czuje się anonimowy. Oczywiście poczucie anonimowości ma charakter iluzoryczny a kanał jakim są media społecznościowe wyzwalają większą emocjonalność wypowiedzi, która przybiera skrajny charakter co jest determinowane przez grupę w której dana osoba uczestniczy a nierozładowane konflikty są tłumione przez użytkowników w postaci bardzo rozległych i emocjonalnych wypowiedzi. Użytkownicy Facebooka, używając hejtu próbują $w$ ten sposób wywierać wpływ na innych, którzy myślą inaczej w inny sposób reprezentując odmienną optykę patrzenia na świat.
Dodatkowo w świecie wirtualnym o wiele łatwiej prowadzić kłótnię i obrażać się niż w realnych okolicznościach, w których dana osoby się znajduje. Można zatem stwierdzić, że media społecznościowe potęgują hejt, bowiem wtedy osoby nie patrza sobie w oczy a tym samym nie kontrolują swoich emocji co przejawia się w destrukcyjnym wypowiadaniu się i obrażaniu wszystkich innych 17 .

Prezentacja swoich poglądów może również prowadzić do zrywania danych przyjaźni a tym samym niszczenia swoich więzów, co w dalszych etapach powoduje chaos w życiu człowieka. Mowa nienawiści wiąże się z pojęciem mowy pogardy gdzie poprzez wygłaszanie swoich poglądów osoba dokonuje deprecjacji drugiego użytkownika, porównując lub przypisując mu negatywne konotacje. W oficjalnych dokumentach Rada Europy stwierdza iż mowa nienawiści obejmuje wszelkie formy wypowiedzi, które szerzą, propagują czy usprawiedliwiają nienawiść o podłożu rasistowskim, ksenofobię, antysemityzm czy inne formy nietolerancji drugiego człowieka (w tym przypadku chodzi o agresywny nacjonalizm, etnocentryzm, wrogość wobec mniejszości, imigrantów itp. $)^{18}$.

Podobną definicję można znaleźć w publikacji pod redakcją R. Wieruszewskiego M. Wyrzykowskiego, A. Bodnara czy A. Gliszczyńskiej-Grabias. Autorzy ci przyjmują że mowa nienawiści to wypowiedź pisemna, ustna lub symboliczna, która czyni przedmiotem ataku jednostkę lub grupę

\footnotetext{
${ }^{17}$ http://polskamasens.pl/skazani-na-hejt-rozmowa-o-facebookowych-wojnach, data wejścia 11.07.2018.

${ }^{18} \mathrm{http}: / /$ www.mowanienawisci.info/post/rada-europy/, data wejścia 12.07.2018.
} 
osób ze względu na kryterium rasy, pochodzenia etnicznego, narodowego, religii, języka, płci, wieku, niepełnosprawności, cech zewnętrznych, orientacji seksualnej i tożsamości płciowej, statusu społecznego czy przekonań politycznych. Mowa nienawiści może zastraszać, grozić, poniżać, obrażać, utrwalać stereotypy i prowadzić do dyskryminacji, a nawet przemocy fizycznej19.

L. Nijakowski przyjmuje, że mowa nienawiści cechuje się następującymi wyznacznikami:

- nadmiernym uogólnianiem negatywnej cechy - negatywne stereotypy grup obcych;

- przypisywaniem szczególnie negatywnych cech;

- uwłaczająca leksyką;

- lekceważeniem, podważaniem rytuałów poważania;

- czy stosowaniem katalogów i zestawień - np, w stosunku do Żydów 20 .

Inni autorzy podejmujący się analizy pojęcia mowa nienawiści zauważają że jest to wypowiedź mająca na celu wyrazić wrogość lub niechęć wobec osoby czy grupy osób ze względu na jej tożsamość etniczną, religijną, rasową czy seksualną. Jej celem jest wzbudzenie strachu w ofiarach przeciwko którym jest skierowana. Mowa nienawiści tym różni się od hejtu, że u jej fundamentów leży wroga postawa wobec konkretnego rodzaju tożsamościowej obcości i pragnienie jej wykluczenia z życia społecznego 21 .

Zdaniem K. Krejtz mowa nienawiści jest pewnego rodzaju kulturą obrażania jednych ludzi przez drugich ${ }^{22}$. Wg innych badaczy mowa nienawiści może być pewnego rodzaju negatywnym zachowaniem, cechą języka ${ }^{23}$ populistycznego, nastawionego na walkę i prowokację 24 a także samym pojęciem służącym do dyskredytowania przeciwnika ${ }^{25}$. Mowa nienawiści zatem to jakakolwiek wypowiedź, gest czy zachowanie, pismo oraz przekaz, które są zabronione, ponieważ mogą podburzać do przemocy lub szkodliwego działania przeciwko chronionej jednostce lub grupie a także mogą skupiać się na zastraszaniu jednostki lub grupy 26 . Z mową nienawiści wiążą się czyny kryminogenne, które mogą być popełnione z nienawiści, lub stanowia uzupełnieniem kultury obrażania ${ }^{27}$.

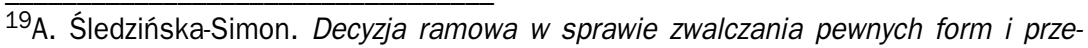
jawów rasizmu, ksenofobii jako kompromis wobec mowy nienawiści w Unii Europejskiej, [w:] R. Wieruszewski, M. Wyrzykowski, A. Bodnar, A. Gliszczyńska-Grabias (red.). Mowa nienawiści a wolność słowa. Aspekty prawne i społeczne. Warszawa. 2010. s. 94. 23 M. Szymczak (red.). Słownik języka polskiego. t. 2. Warszawa. 1988. s. 211.

${ }^{20}$ L. Nijakowski. Mowa nienawiści w świetle teorii dyskursu, [w:] A. Horolets (red.). Analiza dyskursu w socjologii i dla socjologii. Toruń. 2008. s. 113-133.

${ }^{21}$ https://edukacjamedialna.edu.pl/lekcje/hejt-i-mowa-nienawisci, data wejścia 13.07.2018.

${ }^{22}$ K. Krejtz, (red.). Internetowa kultura obrażania? Warszawa. 2012.

${ }^{23}$ K. Ożóg. Pauperyzacja języka współczesnej polityki. LingVaria. 2006. nr 1. s. 81-90.

${ }^{24}$ S. Matlak. Status ontologiczny mowy nienawiści. Naukowy Przegląd Dziennikarski. 2017. nr 4. s. 107.

25 Ibidem. s. 108.

26Jak zamalowywać hejty? Podręcznik. s. 4. źródło: http://news.hejtstop.pl/wp-content/: uploads/2015/05/podrecznik 165x240 web.pdf, data wejścia 14.07.2018.

27 Ibidem.
} 
Jak już wspomniano o wiele częściej kultura pogardy ma miejsce w Internecie co z kolei jest kojarzone z cyberprzemocą. Z badań jakie prowadzono w Polsce wynika, że 40 \% badanych młodych ludzi w wieku 13-17 lat doświadczyło przejawów mowy nienawiści. Ci młodzi ludzie bardzo często doświadczali przykrych doznań co przejawiało się z licznych zaburzeniach $w$ postaci depresji, nerwicy czy stanów lękowych 28 . Mowa nienawiści w znaczeniu prawnym to każdy rodzaj 'złego słowa', motywowanego nienawiścią, a nawet zwykłą niechęcią. W polskim prawie penalizowane jest propagowanie faszystowskiego, lub innego totalitarnego ustroju państwa lub nawoływanie do nienawiści na tle różnic narodowościowych, etnicznych, rasowych, wyznaniowych lub bez względu na bezwyznaniowość29.

Oczywiście nie wszystkie pogardliwe słowa dają podstawę do ścigania z urzędu osoby dopuszczającej się mowy nienawiści. W szczególności nie będzie to możliwe w przypadku tekstów publicystycznych, kojarzonych pejoratywnie jednak nie wpisujących się w dyspozycję polskich przepisów karnych.

W związku z powyższym można wyróżnić cztery poziomy mowy nienawiści; hejt - o którym już pisano wcześniej, obraźliwe zwracanie się do kogoś za pomocą słów definiujących przynależność danej osoby do określonej grupy społecznej, kolejny poziom to nawoływanie do przemocy i zbrodni, ostatni poziom to propagowanie określonego typu narracji nienawiści (propagowanie danego obrazu świata) ${ }^{30}$.

Problematykę mowy nienawiści podjął również administrator Facebooka, który 25 kwietnia 2018 roku wprowadził nowe zapisy regulaminu zakazujące posługiwania się przez jego użytkowników 'brzydkimi' i ohydnymi 'słowami'. Przyjęto że mowa nienawiści na Facebooku będzie wyczerpywała zachowania polegające na atakach na osoby lub grupy osób ze względu na rasę, pochodzenie, narodowość, wyznanie, orientację seksualną, płeć, tożsamość płciową, niepełnosprawność czy chorobę bądź imigrantów. W regulaminie dodatkowo zapisano że mowa nienawiści to będzie każda forma propagowania przemocy, odczłowieczenia31, czy wyszydzania. Dodatkowo zapisano że za mowę nienawiści będzie uznawane każde twierdzenie o niższości danej osoby, mające na celu pogardę, obrzydzenie, wykluczenie czy segregację 32 .

W praktyce nazwanie kogoś zdeformowanym, niedorozwiniętym,

28J. Włodarczyk. Mowa nienawiści w Internecie w doświadczeniu polskiej młodzieży. Fundacja Dzieci niczyje. Uniwersytet Warszawski. www.dzieckokrzywdzone.pl, data wejścia 15.07.2018.

${ }^{29}$ D. Bychawska-Siniarska, D. Głowacka. Mowa nienawiści w Internecie; jak z nią walczyć. Warszawa. 2013. s. 54-70.

${ }^{30}$ A. Demczuk. Postprawda i mowa nienawiści jako nowe narzędzia prowadzenia polityki w społeczeństwie informacyjnym, [w:] T. Grabowski, M. Łakomy, K. Oświęcimski (red). Postprawda jako zagrożenie dyskursu publicznego. Kraków. 2018. s. 171-172.

${ }^{31} \mathrm{Na}$ przykład odniesienie lub porównanie do zwierząt uznawanych kulturowo za gorsze pod względem inteligencji.

${ }^{32}$ http://www.dlahandlu.pl/e-commerce/wiadomosci/facebook-uscisla-czym-jestmowa-nienawisci,70034.html, data wejścia 15.07.2018. 
odrażającym czy brzydkim świadczy o pogardzie dla danej osoby. Również napisanie iż ktoś jest opóźniony w rozwoju, kretynem, posiada niskie IQ, czy jest głupkiem bądź idiotą także jest usuwane przez administrację. Podobnie epitet puszczalska, oszust czy skąpiec stanowi hate speech w rozumieniu regulaminu Facebooka. Użycie słów nienawidzę, nie lubię, A-jest najgorszy, ohydny, paskudny, obrzydliwy kwalifikuje się do usunięcia. Wydaje się że polityka Facebooka zaszła za daleko bowiem może on dość istotnie ingerować $w$ codzienne interakcje mające miejsce na portalu. Zatem nazwanie kogoś 'świnią' jest kwalifikowane jako podstawa do ukarania33. Owa polityka doprowadziła do tego iż administratorzy Facebooka potraktowali jako mowe nienawiści Deklarację Niepodległości34. Jak później tłumaczono zawiodły algorytmy, odpowiedzialne za rozpoznawanie mowy pogardy 35 .

Czy zatem obecnie nie ma mowy nienawiści na Facebooku. Otóż nic bardziej mylnego. Analizując poszczególne wpisy, z czerwca 2018 roku można wskazać przynajmniej na kilka przykładów kultury pogardy w stosunku dla innych osób czy grup osób. 'Wszystkiemu winni ci żydz'”... 'obecny rząd do piachu', 'pan minister to niedorozwinięty imbecy', poset $X$ jest totalnym $h . .$. ', 'ojciec T. to zwykly cham i prostak, do tego oszukuje starszych ludzi'. Ponadto spotkać można również pogarde związaną ze sprawami bieżącej polityki. Przykładem jest wpis - TRZEBA ZNISZCZYĆ PIS I KLER A ZWŁASZCZA RYDZYKA NA STOS Z NIMI!!36. To tylko jeden $z$ wielu które codziennie są umieszczane na facebooku. Szczególnie obecnie kiedy w Polsce trwa wielki spór o zasady powoływania organów sądowniczych i sędziów. Oczywiście nie byłoby w tym nic zdrożnego, jednak wydaje się że używanie mowy nienawiści w takich przypadkach nie jest na miejscu a tym samym narusza mimo wszystkich pozytywnych intencji autorów dobra osobiste obrażanych.

To tylko wybrane przykłady mowy pogardy jakie znalazły się i znajduja codziennie na popularnym Facebooku. Oczywiście zostają one prewencyjne usunięte, jednak nie brakuje pojawiających się nowych określeń w stosunku do mniejszości narodowych, niepełnosprawnych, czy rządu. Polityka jest szczególnym tematem w ramach którego wielu użytkowników portalu stara się w bardzo emocjonalny sposób oddać swoje

\footnotetext{
33https://ithardware.pl/aktualnosci/nazwij kogos swinia glupim lub brzydkim to d ostaniesz bana na faceboo; https://www.facebook.com/jurgen.bergmann.77770?fref= ufi, data wejścia 22.07.2018.

${ }^{34}$ Dokument ten deklarował powstanie nowego państwa na terenie 13 brytyjskich kolonii w Ameryce Północnej. Kartę ratyfikowano 4 lipca 1776 roku w Filadelfii; P. Finkelman, Affirmative action for the master class: the creation of the proslavery constitution. Akron Law Review. 1999. t. 32. nr 3. s. 424; S. Levinson. Compromise and constitutionalism. Pepperdine Law Review. 2011. t. 38. s. 821-944; https://bezprawnik.pl/ algorytmy-facebooka/, data wejścia 15.07.2018.

${ }^{35}$ Totalny obłęd Facebooka. http://telewizjarepublika.pl/totalny-obled-facebookauznal-historyczny-dokument-za-mowe-nienawisci,67516.html, data wejścia 15.07.2018.

${ }^{36} \mathrm{https://www.facebook.com/jurgen.bergmann.77770?fref=ufi}$, data wejścia 22.07.2018.
} 
myśli. Niestety bardzo często formułując taki przekaz korzystają z słów, które są niedostępne i jednoznacznie pejoratywne.

Facebook stwarza naprawdę wiele nowych możliwości z których należy umiejętnie korzystać. Niestety jak już wspominano dość często jest on jedynie platformą na której ludzie puszczają wodze swojej fantazji, propagują kulturę nienawiści czy specjalnie wchodzą w takie dyskusje generujące konflikty. 0 ile w normalnych interakcjach społecznych, człowiek inaczej się zachowuje, to w przypadku portalu społecznościowego, nie ma on jakby hamulców przed niestandardowymi zachowaniami.

Istotnym novum jakie od pewnego czasu pojawia się na portalach społecznościowych w tym na Facebooku są tzw. deepfake czyli fałszywe filmiki przedstawiające znane osoby w niedwuznacznych rolach. W filmikach tych przedstawia się twarze znanych ludzi w celu poniżenia ich. Kiedy to pojawia się w Internecie narusza dobra osobiste takiej osoby a tym samym autor może liczyć się z konsekwencjami prawnymi, w szczególności jeśli chodzi o pozwy prywatne bo zarówno ani Policja ani prokuratura nie ściga tego typu działań. Jak można zatem zauważyć coraz częściej sfera publiczna - social mediów staje się areną mowy nienawiści czy propagowaniu i przedstawianiu znanych osób w niekorzystnym świetle aby ich zdyskredytować. Usunięcie takiego filmiku z sieci jest problematyczne, w szczególności wtedy kiedy autor nie jest znany37.

W Polsce prowadzi się dość szeroko zakrojoną dyskusję $w$ jaki sposób zwalczać tego typu posty, filmiki czy inne twory zawierające ładunki mowy nienawiści. Oczywiście nie istnieje idealne rozwiązanie tego problemu, jednak jak wskazuja zainteresowani w innych państwach wprowadzono nowe prawo regulujące odpowiedzialność za mowę nienawiści w mediach społecznościowych.

W Niemczech obowiązujące regulacje prawne nakładają na portale społecznościowe obowiązek usuwania tego typu postów. W przypadku zaniechania tego, na portal społecznościowy może zostać nałożona kara w wysokości do 50 mld euro, co jest znaczącą dolegliwością dla potencjalnego właściciela, mimo że portal bardzo często jest częścią korporacji medialnej.

Prawo to dotyczy Instagrama, Twittera, Facebooka, Snapchata, Google+ i YouTube'a, ale nie mediów społecznościowych łączących profesjonalistów, takich jak Linkedln i komunikatorów takich jak WhatsApp. ${ }^{38}$. Owe przepisy mimo swojego prewencyjnego działania wzbudzają jednak liczne polemiki. Otóż właściciele portali społecznościowych zarzucają rządowi że nakłada na nich karę a faktycznym autorem danego postu jest zupełnie inna osoba. To z kolei powoduje że w zasadzie każdy obraźliwy post zostaje natychmiast skasowany, co jest przez niektórych kojarzone wręcz z cezurą.

\footnotetext{
${ }^{37}$ R. Kamiński. Fałszywe video. Komputer Świat. 2018. nr 8. s. 18-19.

${ }^{38}$ Niemcy się nie patyczkują - $50 \mathrm{mln}$ euro kary za mowę nienawiści w mediach społecznościowych. https://www.spidersweb.pl/2018/01/niemcy-facebook-kary-mowa-nienawisci.html, data wejścia 11.07.2018.
} 
Jeśli chodzi o grupy w których jest skierowana mowa nienawiści to wg. badań niemieckich są to najczęściej posty uderzające $\mathrm{w}$ imigrantów i uchodców. Jak widać ten problem jest $w$ orbicie ciagłych spekulacji i wymiany nie zawsze zgodny z zasadami odpowiedniej kultury zachowania na portalach społecznościowych a jego źródło wiążę się z problemem z jakim boryka się Europa a mianowicie kwetsią przyjmowania uchodźców i imigrantów. Mowa nienawiści jest także skierowana do muzułmanów, którzy często są przestawiani jako bestie, orki lub inne nieludzkie stworzenia. od takiego dehumanizacyjnego nazewnictwa rozpoczyna się mowa nienawiści, która jak wskazują niektórzy autorzy kończyć się może nawet na ludobójstwie ${ }^{39}$ co jednak w moim przekonaniu jest przesadzone ale w dzisiejszym świecie możliwe. Mowa nienawiści również skierowana jest do gejów, Romów, wyznawców islamu, osób transeksulanych czy feministek ${ }^{40}$. Jeśli chodzi o źródła mowy nienawiści to inaczej sprawa przedstawia się $\mathrm{w}$ przypadku młodzieży a odmiennie jeśli chodzi o osoby dorosłe.

W przypadku młodzieży znaczna cześć osób spotyka się z mową nienawiści w Internecie, który stanowi dla tych osób typowe środowisko w którym publikują, piszą czy prowadzą różne swoje przedsięwzięcia. Rzadziej młodzi spotykają się z zachowaniami w których używa się mowy pogardy podczas rozmów, a najrzadziej w miejscach publicznych. Młodzi ludzie stykając się z mową nienawiści łatwo ją przyswajają i są gotowi do naruszania podstawowych zasad współżycia społecznego wraz z przemocą fizyczną. Inaczej sprawia przedstawia się w przypadku osób dorosłych, dla których Internet nie jest wyznacznikiem statusu społecznego ani kultury uczestnictwa w życiu społecznym.

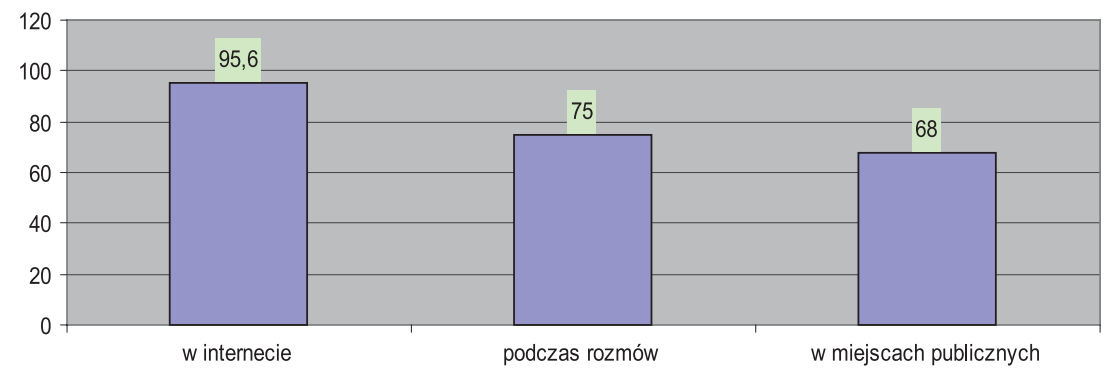

Wykres 1. W jakich miejscach z mową nienawiści najczęściej spotyka się młodzież (dane w \%)

Źródło: Opracowanie własne na podstawie https://www.kson.pl/1725-mowanienawisci-mowa-pogardy-prezentacja-raportu-czym-nam-grozi-mowa-nienawisci, data wejścia 22.07.2018.

\footnotetext{
${ }^{39}$ https://www.deon.pl/religia/kosciol-i-swiat/komentarze/art,2880,mowa-nienawisci-a-wylegarnie-terrorystow.html, data wejścia 22.07.2018.

${ }^{40}$ https://www.kson.pl/1725-mowa-nienawisci-mowa-pogardy-prezentacja-raportuczym-nam-grozi-mowa-nienawisci, data wejścia 22.07.2018.
} 
W tym przypadku osób dorosłe podają że ich spotkania z mową nienawiści to przede wszystkim programy telewizyjne (różnego pochodzenia) w których najczęściej politycy budują kulturę pogardy w stosunku do wybranych grup społecznych. Rzadziej spotykają się z incydentami podczas rozmów i w miejscach publicznych. Można zatem stwierdzić że dla osób dorosłych owym głównym medium z którego czerpią i zarazem spotykają kulturę obrażania stanowi telewizja.

W Polsce również zaczęto pracę na regulacjami prawnymi sankcjonującymi mowę nienawiści na facebooku. Ministerstwo Cyfryzacji podało że przypadki mowy nienawiści mieli by zgłaszać sami internauci, a ich rozstrzyganiem miałby się zajmować niezawisły sąd. Pewnego rodzaju propozycją było uruchomienie sądów 24 godzinnych, które zajmowałyby się tego rodzaju narusze- niami ${ }^{41}$. Niestety póki co projekt ustawy regulującej tę sferę upadł, zakwestionował go rządzący PIS, podobne projekty zostały przygotowane przez Nowoczesną i inne ugrupowania, jednak również podzieliły los ustawy zgłoszonej przez Prawo i Sprawiedliwość.

Tym samym w maju 2018 roku, na Facebooku miał miejsce incydent, w wyniku którego w Żarach został zatrzymany mężczyzna, który na facebooku nawoływał do popełnienia przestępstw wobec polskich parlamentarzystów. Nawoływał on między innymi do popełnienia szeregu przestępstw przeciwko parlamentarzystom, pisał również aby w Polsce zorganizować coś na wzór Majdanu. Człowiek ten został zatrzymany i oddany w ręce niezawisłego sądu 42 .

Administracja facebooka podała, że w okresie między 2017 a 2018 rokiem usunięto 837 milionów nie-

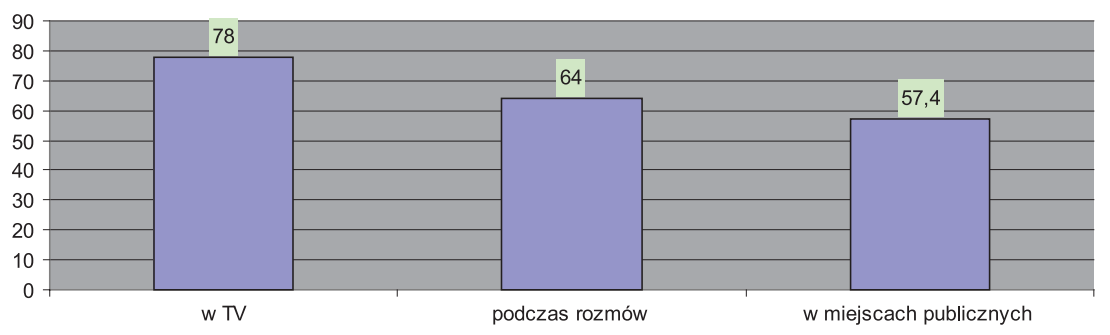

Wykres 2. W jakich miejscach z mową nienawiści najczęściej spotykają się dorośli (dane w \%)

Źródło: Opracowanie własne na podstawie https://www.kson.pl/1725-mowanienawisci-mowa-pogardy-prezentacja-raportu-czym-nam-grozi-mowa-nienawisci, data wejścia 22.07.2018.

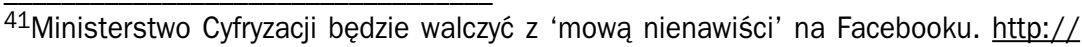
shareinfo.pl/ministerstwo-cyfryzacji-bedzie-walczyc-z-mowa-nienawisci-na-facebooku/, data wejścia 22.07.2018.

${ }^{42}$ Internauta zatrzymany za mowę nienawiści. Namawiał do atakowania parlamentarzystów. https://www.tvp.info/37129504/internauta-zatrzymany-za-mowe-nienawiscinamawial-do-atakowania-parlamentarzystow, data wejścia 22.07.2018.
} 
prawdziwych kont, $21 \mathrm{mln}$. wpisów propagujących aktywność seksualną, 2,5 mln postów szerzących mowę nienawiści ${ }^{43}$. Jak zatem można skonstatować mowa nienawiści jest realnym zagrożeniem na portalach społecznościowych. 0 ile dotyka ona całe rzesze społeczne o tyle bardzo często autorami obraźliwych stwierdzeń są coraz młodsi ludzie. Nie mają oni zahamowań do propagowania kultury obrażania, nie wiele czynią sobie z ewentualnej odpowiedzialności prawnej a tym samym nie wiedzą że poprzez swoje zachowanie mogą zadań cierpienia swoim kolegom czy koleżankom.

Popularność facebooka, tym bardziej wzmacnia destrukcyjne zachowania osób propagujących mowę nienawiści, które postępują często nie zważając na uczucia innych, a przypomnieć należy że mowa nienawiści najbardziej wpływa na psychikę drugiego człowieka, którą w skrajnych sytuacjach może znacząco osłabiać. W związku z powyższym należy piętnować wszelkie zachowania mające na celu poniżanie, oczernianie czy obrażanie innych osób, tym bardziej że wprowadzają one wiele destrukcji w system psychospołeczny młodych, wrażliwych osób.

\section{Podsumowanie}

Wielowymiarowość i łatwy dostęp do Internetu sprawiają że stał się on prostym narzędziem do generowania zjawisk szkodliwych, patologii społecznych, przestępczości, ukrytego sterowania zachowaniami osób w nim funkcjonujących czy szerzeniem mowy nienawiści. Owa kultura obrażania szczególnie na portalach społecznościowych bardzo często wykracza poza sferę wirtualną na ma wiele negatywnych konsekwencji w życiu osobistym każdej jednostki. Bardzo często dotyka ona tego co jest dla ludzi bardzo ważne, czyli godności, reputacji, czy aspektów wolnościowych. Szczególnie na facebooku, jest to odczuwalne kiedy jesteśmy zalewani nienawistnymi komentarzami pod swoim adresem czy wpisem 44 . Zastanawiające jest dlaczego ludzie posługują się mową nienawiści.

Z przeprowadzonych badań wynika, że używanie kultury pogardy przynosi ulgę, euforię, i poczucie pewnego rodzaju sprawiedliwości. Dość charakterystyczne jest jednak to że osoba wobec której na portalu społecznościowym używamy niecenzuralnych słów tak naprawdę nie wyrządziła nam żadnej krzywdy, a po prostu miała inne od nas zdanie na dany temat. Drugą przyczyną dla której poszczególne osoby używają mowy nienawiści jest fakt iż każdy jest zdolny do czynienia zła. Polega to na tym że kiedy widzimy jakieś negatywne komentarze na dany temat, to bardzo chętnie do nich dołączamy używając mowy pogardy w stosunku do osoby, która miała czy wyraziła odmiennie zdanie niż my. Niebagatelny wpływ ma również sytuacja i medium którym się posługujemy. Otóż Internet daje nam anonimowość i pośredniość. To z kolei powoduje że nie mówimy

\footnotetext{
${ }^{43}$ http://www.komputerswiat.pl/nowosci/internet/2018/20/facebook-chwali-sieliczbami-usunieto-mnostwo-kont-oraz-spamu.aspx, data wejścia 22.07.2018.

${ }^{44}$ http://www.gazetaprawna.pl/artykuly/1014669,mowa-nienawisci-w-sieci-ma-konsekwencje-w-zyciu-codziennym.html, data wejścia 31.07.2018.
} 
ludziom pewnych rzeczy wprost a to jest o wiele prostsze, dlatego bardzo często niektóre jednostki posługują się mową nienawiści, z jednej strony uważając że są anonimowi z drugiej iż nie widzą relacji ani emocji na twarzy osoby obrażanej.

Dość często używanie mowy pogardy determinują pewnego rodzaju stereotypy i uprzedzenia (Np. obrażanie Żydów, Romów czy innych osób ze względu na ich orientację, pochodzenie, rasę itp). Wreszcie ostatnim czynnikiem mogącym mieć wpływ na nasze zachowanie a tym samym używanie mowy nienawiści jest ludzka zazdrość. Osoba niezadowolona ze swojej pozycji czy sytuacji życiowej mająca za sobą pewne przykre doświadczenia, o wiele częściej posługuje się w stosunku do innych mową nienawiści. W takiej sytuacji twierdzi się że mowa nienawiści jest skutkiem frustracji życiowej45. Używanie mowy pogardy na Facebooku niesie za sobą wiele negatywnych konsekwencji. Przede wszystkim jest to wpływ na psychikę drugiego człowieka, o której jeszcze nie dawno tak często nie pisano. Przede wszystkim ofiara mowy nienawiści czuje, że obniża się jej poczucie własnej wartości. Po pewnym czasie następuje obniżenie jej wartości i z czasem staje się mniej odporna na tego typu ekscesy.

W konsekwencji zaczyna ona wierzyć że jakiekolwiek stawienie oporu, komentowanie itp nie mają sensu. Ofiara mowy nienawiści za- czyna się żyć własnym życiem, zamyka się w sobie, przestaje utrzymywać kontakty międzyludzkie, zaczyna bać się o swoje życie, izoluje się od reszty społeczeństwa. W dalszym etapie mogą u niej wystąpić już konkretne zaburzenia chorobowe w postaci nerwicy lękowej, depresji czy innych jednostek chorobowych 46 . W końcowym stadium kiedy mowa nienawiści doprowadzi do destrukcyjnych zmian w umyśle ofiary, może ona sprowadzić swoje życie do absurdu i próbować popełnić samobójstwo. Mowa nienawiści jest takim typem przemocy, na którym cierpią nie tylko osoby, do których jest ona skierowana, ale wszyscy którzy są w jej zasięgu, gdyż osłabia ona ogólne normy trwałego i harmonijnego współżycia społecznego. Ustawodawca polski próbował wprowadzić określone kary za posługiwanie się mową nienawiści w Internecie ale póki co nie znaleziono tzw 'złotego środka'. Mimo tego najwięcej problemu użytkownikom sieci sprawia nie zwracanie uwagi na nią lub ignorowanie obraźliwych komentarzy47.

Według licznych badań psychologicznych jeśli będziemy reagować na agresywne komentarze, to jeszcze bardziej eskalujemy je i podburzamy samego agresora. W związku z powyższym należałoby nie reagować na komentarze a jedynie co to zgłaszać takie przypadki administratorowi, który może usunąć komentarz lub zablokować osobę dopuszczającą się mowy nienawiści ${ }^{48}$. Równie

\footnotetext{
${ }^{45}$ http://www.poradnikzdrowie.pl/psychologia/emocje/hejt-czyli-o-mowie-nienawisciw-internecie-przyczyny-i-konsekwencje-hejtu 45623.html, data wejścia 31.07.2018.

46/bidem.

${ }^{47}$ http://www.diakonia.org.pl/aktualnosc/seminarium-o-dobrej-komunikacji/, data wejścia 31.07.2018.

${ }^{48}$ http://www.poradnikzdrowie.pl/psychologia/emocje/hejt-czyli-o-mowie-nienawisciw-internecie-przyczyny-i-konsekwencje-hejtu 45623.html, data wejścia 31.07.2018.
} 
ważne są wyzwanie dla instytucji edukacyjnych i organizacji pozarządowych w kwestii prowadzenia szkoleń, warsztatów czy akcji społecznych mających uświadamiać czy jest owa mowa pogardy, jak sobie z nią radzić, jaką rodzi ona odpowiedzialność karną na gruncie przepisów prawa.

\section{Refereces}

1. Bąk, A. (2016). Serwisy społecznościowe - efekt Facebooka i nie tylko. Journal of Media i Społeczeństwo: medioznawstwo, komunikologia, semiologia, socjologia mediów, Tom 6, Bielsko-Biała [in Polish].

2. Bychawska-Siniarska, D. \& Głowacka, D. (2013). Mowa nienawiści w Internecie; jak z nią walczyć. Warszawa [in Polish].

3. Demczuk, A. (2018). Postprawda i mowa nienawiści jako nowe narzędzia prowadzenia polityki w społeczeństwie informacyjnym, [w:] T. Grabowski, M. Łakomy, K. Oświęcimski (red), Postprawda jako zagrożenie dyskursu publicznego. Kraków [in Polish].

4. Facebook przyznaje, że algorytmy nie radzą sobie z mową nienawiści $i$ pokazuje ciekawe statystyki. Retrieved from https://www.spidersweb.pl/2018/ 05/facebook-mowa-nienawisci.html [in Polish].

5. Finkelman, P. (1999). Affirmative action for the master class: the creation of the proslavery constitution. Journal of Akron Law Review, t. 32, nr. 3 [in English].

6. Frankowski, P. \& Juneja, A. (2009). Serwisy społecznościowe. Budowa, administracja i moderacja. Gliwice [in Polish].

7. Garwol, K. (2017). Rola mediów społecznościowych w edukacji — stan obecny i perspektywy rozwoju. Journal of Dydaktyka Informatyki, 12 [in Polish].

8. Getting Started, w: Facebook Politics \& Government. Retrieved from https://politics.fb.com [in English].

9. Grębosz, M. \& Siuda, D. \& Szymański, G. (2016). Social media marketing. Łódź [in Polish].

10. Gruszczyk, A. (2018). Moja prawda jest najmojsza czyli postprawda w praktyce [w:] T. Grabowski, M. Łakomy, K. Oświęcimski (red), Postprawda jako zagrożenie dyskursu publicznego. Kraków [in Polish].

11. Retrieved from http://polskamasens.pl/skazani-na-hejt-rozmowa-o-facebookowych-wojnach [in Polish].

12. Retrieved from http://www.diakonia.org.pl/aktualnosc/seminarium-odobrej-komunikacji/, data wejścia 31.07.2018 [in Polish].

13. Retrieved from http://www.dlahandlu.pl/e-commerce/wiadomosci/facebook-uscisla-czym-jest-mowa-nienawisci,70034.html [in Polish].

14. Retrieved from http://www.gazetaprawna.pl/artykuly/1014669,mowanienawisci-w-sieci-ma-konsekwencje-w-zyciu-codziennym.html [in Polish].

15. Retrieved from http://www.komputerswiat.pl/nowosci/internet/2018/ 20/facebook-chwali-sie-liczbami-usunieto-mnostwo-kont-oraz-spamu.aspx [in Polish].

16. Retrieved from http://www.mowanienawisci.info/post/rada-europy [in Polish].

17. Retrieved from http://www.poradnikzdrowie.pl/psychologia/emocje/hejtczyli-o-mowie-nienawisci-w-internecie-przyczyny-i-konsekwencje-hejtu 45623.html [in Polish].

18. Retrieved from https://edukacjamedialna.edu.pl/lekcje/hejt-i-mowa-nienawisci [in Polish]. 
19. Retrieved from https://ithardware.pl/aktualnosci/nazwij kogos swinia glupim lub brzydkim to dostaniesz bana na facebooku-5937.html [in Polish].

20. Retrieved from https://www.deon.pl/religia/kosciol-i-swiat/komentarze/art,2880,mowa-nienawisci-a-wylegarnie-terrorystow.html [in Polish].

21. Retrieved from https://www.facebook.com/jurgen.bergmann. 77770?fref=ufi [in Polish].

22. Retrieved from https://www.kson.pl/1725-mowa-nienawisci-mowa-pogardy-prezentacja-raportu-czym-nam-grozi-mowa-nienawisci [in Polish].

23. Internauta zatrzymany za mowę nienawiści. Namawiał do atakowania parlamentarzystów. Retrieved from https://www.tvp.info/37129504/internautazatrzymany-za-mowe-nienawisci-namawial-do-atakowania-parlamentarzystow [in Polish].

24. Jak zamalowywać hejty? Podręcznik, s. 4., źródło: http://news.hejtstop.pl /wp-content/uploads/2015/05/podrecznik 165x240 web.pdf [in Polish].

25. Kamiński, R. (2018). Fałszywe video. Journal of Komputer Świat, nr 8 [in Polish].

26. Kirpatrick, D. (2011). Efekt Facebooka. Warszawa [in Polish].

27. Krejtz, K. (2012). (red.) Internetowa kultura obrażania? Warszawa [in Polish].

28. Levinson, S. (2011). Compromise and constitutionalism. Pepperdine Law Review, t. 38. Retrieved from https://bezprawnik.pl/algorytmy-facebooka [in Polish].

29. Matlak, S. (2017). Status ontologiczny mowy nienawiści. Journal of Naukowy Przegląd Dziennikarski, nr 4 [in Polish].

30. Media społecznościowe, w: Encyklopedia Powszechna PWN. Retrieved from https://encyklopedia.pwn.pl/szukaj/ media\%20spo\%C5\%82eczno\%C5\%9 Bciowe.html [in Polish].

31. Ministerstwo Cyfryzacji będzie walczyć z 'mową nienawiści' na Facebooku. Retrieved from http://shareinfo.pl/ministerstwo-cyfryzacji-bedzie-walczyc-z-mowanienawisci-na-facebooku [in Polish].

32. Niemcy się nie patyczkują - $50 \mathrm{mln}$ euro kary za mowę nienawiści $\mathrm{w}$ mediach społecznościowych. Retrieved from https://www.spidersweb.pl/2018/ 01/niemcy-facebook-kary-mowa-nienawisci.html [in Polish].

33. Nijakowski, L. (2008). Mowa nienawiści w świetle teorii dyskursu, [w:] A. Horolets (red.), Analiza dyskursu w socjologii i dla socjologii. Toruń [in Polish].

34. Ożóg, K. (2006). Pauperyzacja języka współczesnej polityki. Journal of LingVaria, nr 1 [in Polish].

35. Szczypa, P. \& Lulek, A. (2017). Media społecznościowe jako źródło informacji sprawozdawczych $w$ przyszłości. Zeszyty Uniwersytetu Ekonomicznego w Katowicach. Katowice [in Polish].

36. Szymczak, M. (1988). (red.), Słownik języka polskiego, t. 2. Warszawa [in Polish].

37. Śledzińska-Simon, A. (2010). Decyzja ramowa w sprawie zwalczania pewnych form i przejawów rasizmu, ksenofobii jako kompromis wobec mowy nienawiści w Unii Europejskiej, [w:] R. Wieruszewski, M. Wyrzykowski, A. Bodnar, A. Gliszczyńska-Grabias (red.), Mowa nienawiści a wolność słowa. Aspekty prawne i społeczne. Warszawa [in Polish].

38. Totalny obłęd Facebooka. Retrieved from http://telewizjarepublika.pl/ totalny-obled-facebooka-uznal-historyczny-dokument-za-mowe-nienawisci. 67516.html [in Polish]. 
39. Włodarczyk, J. Mowa nienawiści w Internecie w doświadczeniu polskiej młodzieży. Fundacja Dzieci niczyje. Uniwersytet Warszawski. Retrieved from www.dzieckokrzywdzone.pl [in Polish].

40. Worona, J. (2015). Współczesne zagrożenia w cyberprzestrzeni. Aspekt prawno międzynarodowy, w: D. Morańska (red), Patologie w cyberprzestrzeni. Profilaktyka zagrożeń medialnych. Dąbrowa Górnicza [in Polish].

Digital civilization is developing more rapidly, and modern technology is gaining ground in all spheres of human functioning. The quality of life of individuals immersed in various social networks does not depend on their age, but is determined by the level of personal information competencies. Despite the charms of the virtual world and the opportunities it creates, it also poses certain dangers, and even deadly traps for some of its consumers.

Keywords: language; hate; media; legal aspects; aspects; electronic media.

В статье рассматривается дискурс языка ненависти на страницах некоторых медиа. Анализируются опасения, что они несут, предлагаются средства противодействия. Противодействие расматривается в медиа и юридическом аспектах. Не остаются вне и электронные средства массовой информации.

Ключевые слова: язык; ненависть; медиа; юридические аспекты; аспекты; электронные СМИ.

Рецензент - О. О. Янішевський, канд. філол. наук, доцент, КПІ ім. Ігоря Сікорського 